ISSN: 2302-8556

E-Jurnal Akuntansi Universitas Udayana

Vol.24.3.September (2018):2073-2095

DOI: https://doi.org/10.24843/EJA.2018.v24.i03.p16

\title{
Analisis Faktor-Faktor yang Memengaruhi Kinerja Sistem Informasi Akuntansi Pada BPR di Kota Denpasar
}

\author{
Ida Bagus Gede Agastya Mahardika ${ }^{1}$ \\ I Made Sadha Suardikha ${ }^{2}$ \\ ${ }^{1}$ Fakultas Ekonomi dan Bisnis Universitas Udayana, Bali, Indonesia \\ Email: agastyamhardika@gmail.com,// tlp. 081337018964 \\ ${ }^{2}$ Fakultas Ekonomi dan Bisnis Universitas Udayana, Bali, Indonesia
}

\begin{abstract}
ABSTRAK
Penelitian ini bertujuan untuk mengetahui pengaruh keterlibatan pemakai dalam pengembangan sistem informasi, kemampuan teknik personal pemakai sistem informasi, dukungan manajemen puncak, formalisasi pengembangan sistem informasi, program pelatihan dan pendidikan, keberadaan dewan pengarah sistem informasi, serta lokasi departemen sistem terhadap kinerja sistem informasi akuntansi yang diukur melalui kepuasan pengguna sistem. Populasi dalam penelitian ini adalah 13 Bank Perkreditan Rakyat di Kota Denpasar. Sampel ditentukan dengan metode purposive sampling, sehingga memperoleh sampel sebanyak 76 karyawan yang langsung dijadikan sebagai responden penelitian. Data dikumpulkan dengan metode kuesioner. Teknik analisis yang digunakan yaitu analisis regresi linear berganda. Berdasarkan hasil analisis dari 76 responden diketahui bahwa variabel keterlibatan pemakai dalam pengambangan sistem informasi, kemampuan teknik personal sistem informasi, dukungan manajemen puncak, formalisasi pengembangan sistem informasi, program pelatihan dan pendidikan, keberadaan dewan pengarah sistem informasi, serta lokasi departemen sistem berpengaruh positif dan signifikan terhadap kinerja sistem informasi akuntansi pada BPR di Kota Denpasar.
\end{abstract}

Kata Kunci : Teknologi Informasi, Sistem Informasi Akuntansi, Bank Perkreditan Rakyat

\begin{abstract}
This study aims to determine the influence of user involvement in the development of information systems, the ability of personal techniques users of information systems, top management support, formalization of information systems development, training and education programs, the existence of the information system board of directors, and the location of the department of the system on the performance of accounting information systems as measured by user satisfaction of the system. The population in this research is 13 Rural Banks in Denpasar City. The sample was determined by purposive sampling method, and got 76 employees as the respondents. Data were collected by questionnaire method. The analysis technique used is multiple linear regression analysis. Based on the analysis of 76 respondents it is known that the seven variables have positive and significant effect on the performance of accounting information system at BPR in Denpasar City.
\end{abstract}

Keywords : Information Technology, Accounting Information System, Rural Bank 


\section{PENDAHULUAN}

Perkembangan teknologi informasi telah menyebabkan beralihnya penggunaan sistem informasi yang manual ke sistem informasi yang berbasis komputer. Penerimaan dan pemanfaatan sistem informasi yang berbasis komputer, tidak hanya berfungsi sebagai sarana pendukung untuk meningkatkan kinerja perusahaan, tetapi telah menjadi senjata utama untuk menghadapi persaingan. Penggunaan teknologi informasi diharapkan dapat memberikan manfaat yang besar dalam dunia bisnis yang sangat kompetitif (Wirawan, 2016).

Bidang akuntansi tidak luput dalam perkembangan teknologi sistem informasi. Sistem informasi dalam bidang akuntansi disebut Sistem Informasi Akuntansi (SIA). Sistem Informasi Akuntansi (SIA) adalah suatu struktur dalam suatu entitas, seperti perusahaan bisnis, yang mempekerjakan sumber daya fisik dan komponen lainnya untuk mengubah data ekonomi menjadi informasi akuntansi, dengan tujuan memenuhi kebutuhan informasi dari berbagai pengguna informasi (Dey, 2007).

Penerapan SIA pada sebuah bank menjadi salah satu titik vital pada kegiatan operasionalnya sehari-hari. Dunia perbankan merupakan salah satu sektor industri dengan tingkat penyerapan terhadap teknologi yang tinggi. Industri perbankan dapat dengan mudah mengadopsi perkembangan teknologi SIA ke dalam sistem yang telah diterapkan (Wirawan 2016). Keberhasilan pengembangan dan penerapan sistem informasi akan mudah dicapai, apabila kualitas pemakai sesuai dengan kualitas yang 
ISSN: 2302-8556

E-Jurnal Akuntansi Universitas Udayana Vol.24.3.September (2018):2073-2095

dibutuhkan untuk menjalankan sistem informasi (Sandhu, 2008).

Al-eqab dan Adele (2013) senada dengan Sori (2009) menyatakan bahwa sistem informasi akuntansi sangat penting bagi semua organisasi. SIA merupakan hal yang penting bagi perusahaan dalam hal pengambilan keputusan serta melihat pengaruh lingkungan bisnis dalam skala global. Faktor-faktor yang memengaruhi kinerja SIA sangat berpengaruh terhadap kualitas informasi yang akan disajikan sebagai dasar pengambilan keputusan oleh manajemen serta pihak yang membutuhkan informasi. Penilaian terhadap kinerja SIA merupakan hal yang penting, maka pengungkapan terhadap faktor-faktor yang memengaruhi kinerja SIA perlu dilakukan secara tepat (Utama, 2014).

Jen (2002), Almilia dan Briliantien (2007), Diputra (2012) serta Utama (2014) berpendapat kinerja sistem informasi akuntansi dapat dipengaruhi oleh beberapa faktor yang diantaranya adalah keterlibatan pemakai dalam proses pengembangan sistem informasi, kemampuan teknik personal sistem informasi, ukuran organisasi, dukungan manajemen puncak, formalisasi pengembangan sistem informasi, program pelatihan dan pendidikan pemakai, keberadaan dewan pengarah sistem informasi, serta lokasi departemen sistem informasi.

Diputra (2012) berpendapat bahwa keterlibatan pemakai yang semakin sering akan meningkatkan kinerja SIA dikarenakan adanya pengaruh yang positif antara keterlibatan pemakai dalam proses pengembangan sistem informasi dalam kinerja SIA. Terry (2004) menyatakan bahwa kepuasan pemakai akan meningkat apabila 
didukung oleh keterlibatan pemakai itu sendiri. Dapat disimpulkan semakin banyak partisipasi pengguna dalam pengembangan sistem dapat meningkatkan komitmen dan keterlibatan pemakai sehingga pemakai dapat menerima dan menggunakan sistem informasi dan akhirnya meningkatkan kualitas SIA pada BPR. Komara (2006), Perbarini (2012), Abhimantra (2016) serta Damana (2016) menemukan ada pengaruh positif dan signifikan antara variabel keterlibatan pemakai dalam pengembangan SIA dengan Kinerja SIA namun Almilia dan Briliantien (2007) tidak menemukan adanya pengaruh antar variabel tersebut.

Jen (2002) berpendapat bahwa semakin tinggi kemampuan teknik personal SIA akan meningkatkan kinerja SIA dikarenakan adanya pengaruh yang positif antara kemampuan teknik personal sistem informasi dengan kinerja SIA. Kemampuan teknik yang baik diperoleh melalui pendidikan atau pengalaman pemakai. Kemampuan teknik pemakai yang baik akan mendorong pemakai untuk menggunakan SIA sehingga dapat meningkatkan kinerja SIA pada BPR. Kariyani (2006), Dharmayanti (2015) serta Abhimantra (2016) menemukan adanya pengaruh positif dan signifikan antara variabel kemampuan teknik personal SIA dengan kinerja SIA namun Perbarini (2012) dan Utama (2014) tidak menemukan pengaruh antar variabel tersebut.

Wrastuti (2009) ukuran organisasi umumnya diukur berdasarkan jumlah karyawan. Cudanov, et al. (2010) menyatakan bahwa implementasi informasi dan teknologi dapat dipengaruhi oleh ukuran organisasi. Dalam penelitiannya Diputra 
ISSN: 2302-8556

E-Jurnal Akuntansi Universitas Udayana Vol.24.3.September (2018):2073-2095

(2012) dan Fitri (2012) berpendapat bahwa ukuran organisasi yang diukur berdasarkan jumlah karyawan tidak meningkatkan kinerja SIA dikarenakan tidak adanya pengaruh antara jumlah karyawan dengan kinerja SIA. Penerapan teknologi akan memperkecil jumlah karyawan yang dipekerjakan. Sehingga dalam penelitian ini ukuran organisasi tidak diikutsertakan dalam variabel bebas.

Lau (2004), dukungan manajemen puncak adalah perilaku eksekutif yang berhubungan dengan perencanaan sistem informasi, pengembangan dan implementasinya. Jen (2002) berpendapat bahwa semakin besar dukungan yang diberikan manajemen puncak akan meningkatkan kinerja SIA dikarenakan adanya pengaruh yang positif antara dukungan manajemen puncak dalam proses pengembangan dan pengoperasian SIA dengan kinerja SIA. Semakin besar dukungan dari manajemen puncak akan meningkatkan kinerja SIA pada BPR. Komara (2006), Perbarini (2012), Antari (2015) serta Abhimantra (2016) menemukan adanya pengaruh positif dan signifikan antara variabel dukungan manajemen puncak dengan kinerja SIA namun Ilat, dkk. (2008) dan Utama (2014) tidak menemukan adanya pengaruh antar variabel tersebut.

Utama (2014), formalisasi pengembangan sistem informasi merupakan sistem yang didokumentasikan dengan sistematik dan dikonfirmasi melalui dokumen dapat memengaruhi keberhasilan suatu penerapan sistem informasi. Sistem yang dikembangkan secara sistematik akan meningkatkan kinerja SIA pada BPR. Kariyani (2006), Gunawati (2013) serta Abhimantra (2016) menemukan adanya pengaruh 
positif dan signifikan antara variabel formalisasi pengembangan sistem informasi dengan kinerja SIA namun Almilia dan Briliantien (2007) tidak menemukan adanya pengaruh antar variabel tersebut.

Amrul dan Syar'ie, (2005) menyebutkan, pelatihan merupakan sesuatu yang terpenting guna memberikan latar belakang yang bertujuan mendekatkan pemakai dengan penggunaan teknik komputer secara umum sebagai bagian dari proses penggunaan sistem yang spesifik. Menurut Tian-hui (2009), pelatihan dan pendidikan pemakai bertujuan untuk meningkatkan kesadaran akan informasi dan keterampilan dalam pengambilan keputusan. Begitu pula menurut Nithyanandam, et al. (2006) menyatakan bahwa program pendidikan dibutuhkan untuk memaksimalkan kinerja para pemakainya. Program pelatihan dan pendidikan pemakai mampu meningkatkan kinerja pengguna sehingga meningkatkan kinerja SIA pada BPR. Perbarini (2012), Suryawarman (2012), Damana (2016) dan Abhimantra (2016) menemukan adanya pengaruh signifikan antara program pendidikan dan pelatiahan pemakai dengan kinerja SIA namun Kariyani (2006) dan Utama (2014) tidak menemukan adanya pengaruh antar variabel tersebut.

Diputra (2012) berpendapat bahwa kinerja SIA akan lebih tinggi apabila terdapat dewan pengarah sistem. Dewan pengarah sebagai eksekutif yang bertugas untuk pengembangan, pengarahan, penerapan dan pengendalian jalannya suatu sistem. Tugas tersebut membuat kualitas dari sistem yang digunakan menjadi lebih baik sehingga membuat kinerja SIA pada BPR juga meningkat. Kariyani (2006), 
ISSN: 2302-8556

E-Jurnal Akuntansi Universitas Udayana Vol.24.3.September (2018):2073-2095

Gunawati (2013) dan Antari (2015) menemukan adanya pengaruh positif antara variabel keberadaan dewan pengarah sistem informasi dengan kinerja SIA namun Utama (2014) tidak menemukan adanya pengaruh antar variabel tersebut.

Jen (2002) berpendapat bahwa kinerja SIA akan lebih tinggi bila departemen sistem informasi terpisah dan berdiri sendiri. Pada beberapa organisasi, fungsi sistem informasi diorganisasikan secara terpisah dari fungsi akuntansi dan dibawah tanggung jawab manajer tersendiri yaitu manajer sistem informasi. Menurut Jogiyanto (2005: 109) pemisahan departemen tersebut dikarenakan departemen sistem informasi sebagai service departement tidak hanya mengolah data akuntansi saja, tetapi juga mengolah data non akuntansi. Pemisahan departemen ini mampu memberi pelayanan yang lebih baik sehingga memberikan kinerja SIA yang lebih baik bagi BPR. Diputra (2012), Gunawati (2013) dan Antari (2015) menemukan pengaruh positif antara pemisahan lokasi departemen sistem informasi terhadap kinerja SIA, namun Utama (2014) tidak menemukan adanya pengaruh antar variabel tersebut.

Bank Perkreditan Rakyat (BPR) adalah lembaga keuangan bank yang menerima simpanan hanya dalam bentuk deposito berjangka, tabungan, atau bentuk lainnya yang dipersamakan dengan itu dan menyalurkan dana kepada masyarakat. BPR memiliki peranan penting dalam melayani kepentingan dan kebutuhan masyarakat dibidang jasa keuangan khususnya untuk Usaha Kecil dan Mikro (UKM). BPR harus selalu meningkatkan kinerjanya sehingga dapat tumbuh dengan sehat dan dapat melaksanakan fungsi sesuai dengan yang diharapkan oleh masyarakat dibidang 
jasa keuangan. Kinerja SIA yang baik akan memberikan dampak positif pada bank, sehingga dapat mencapai tujuannya (Wirawan, 2016).

Berdasarkan data Perhimpunan BPR Indonesia (Perbarindo) jumlah BPR di provinsi Bali periode 2017 berjumlah 131 BPR yang tersebar. Di Kota Denpasar saat ini terdapat 13 BPR. Kota Denpasar dipilih sebagai lokasi penelitian Karena ingin mengetahui apakah kinerja SIA pada tiap BPR di Kota Denpasar sudah berjalan dengan optimal mengingat Kota Denpasar memiliki serapan dana terbesar di provinsi Bali. BPR dipilih sebagai objek penelitian karena BPR merupakan suatu lembaga keuangan yang mengalami perkembangan dalam penggunaan sistem informasi berbasis komputer untuk membantu perekonomian pada masyarakat umum dan khususnya untuk UKM.

Berdasarkan latar belakang yang telah disampaikan maka hipotesis yang dapat ditarik adalah sebagai berikut :

$\mathrm{H}_{1}$ : Keterlibatan pemakai dalam proses pengembangan sistem informasi berpengaruh positif terhadap kinerja SIA.

$\mathrm{H}_{2}$ : Kemampuan teknik personal sistem informasi berpengaruh positif terhadap kinerja SIA.

$\mathrm{H}_{3}$ : Dukungan manajemen puncak berpengaruh positif terhadap kinerja SIA.

$\mathrm{H}_{4}$ : Formalisasi pengembangan sistem informasi berpengaruh positif terhadap kinerja SIA.

$\mathrm{H}_{5}$ : Program pelatihan dan pendidikan pemakai berpengaruh positif terhadap kinerja SIA.

$\mathrm{H}_{6}$ : Keberadaan dewan pengarah sistem informasi berpengaruh positif terhadap kinerja SIA. 
$\mathrm{H}_{7}$ : Pemisahan lokasi dari departemen sistem informasi berpengaruh positif terhadap kinerja SIA.

Penelitian ini merujuk pada penelitian yang dilakukan oleh Jen (2002), Diputra (2012) dan Utama (2014) dimana penelitian ini menggunakan tujuh variable bebas yaitu: keterlibatan pemakai dalam proses pengembangan sistem informasin kemampuan teknik personal sistem informasi, dukungan manajemen puncak, formalisasi pengembangan sistem informasi, program pelatihan dan pendidikan pemakai, keberadaan dewan pengarah sistem informasin, dan lokasi dari departemen sistem informasi, serta kinerja sistem informasi akuntansi yang diukur menggukanan kepuasan pengguna sistem sebagai variabel terikat. Berdasarkan pernyataan tersebut dapat digambarkan desain penelitian sebagai berikut: 


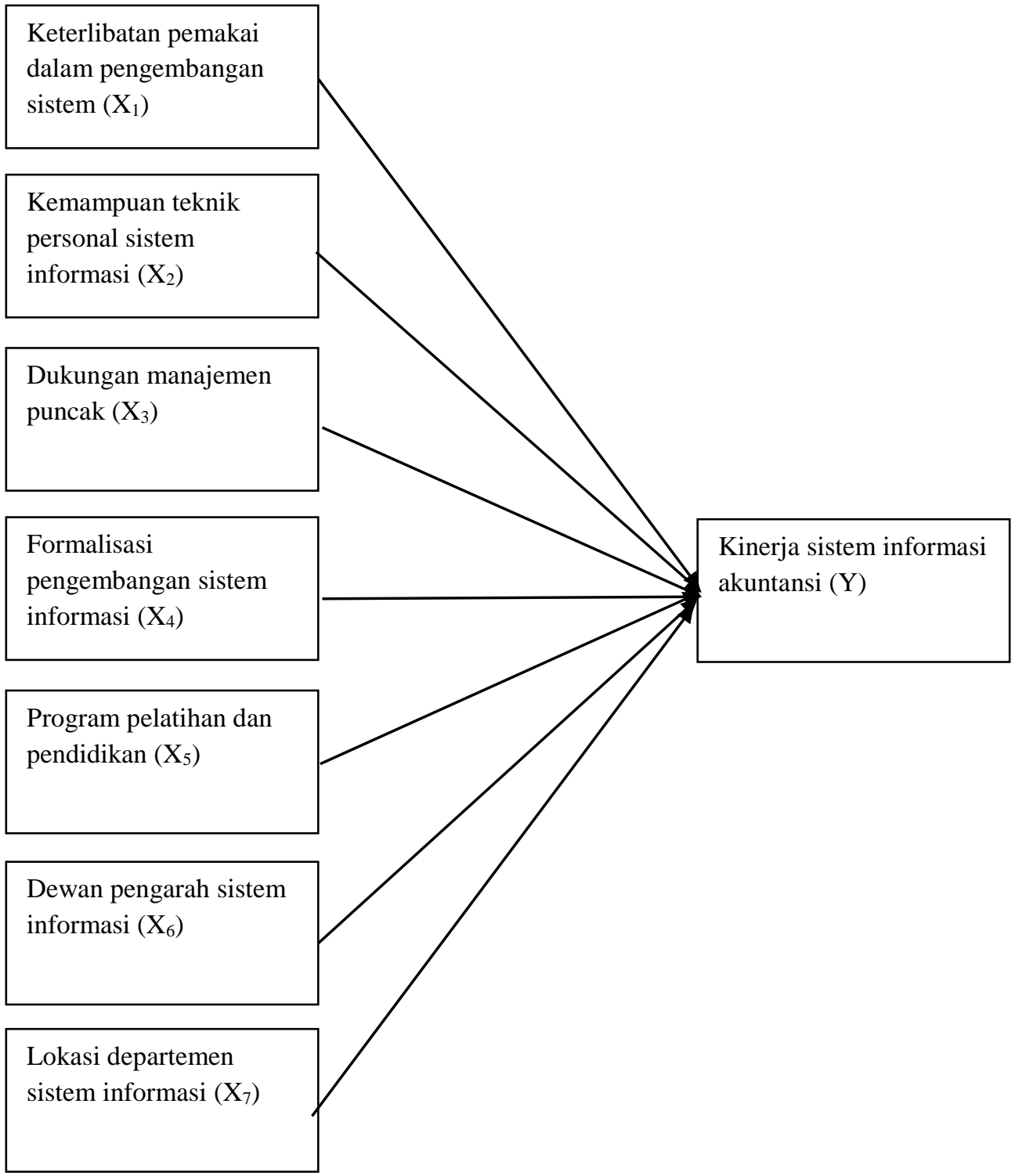

Gambar 1. Desain Penelitian

\section{METODE PENELITIAN}

Penelitian ini berlokasi di Bank Perkreditan Rakyat (BPR) di Kota Denpasar. Lokasi ini dipilih sebagai lokasi penelitian karena peneliti ingin mengetahui apakah kinerja SIA pada tiap BPR di Kota Denpasar sudah berjalan dengan optimal mengingat Kota 
ISSN: 2302-8556

E-Jurnal Akuntansi Universitas Udayana Vol.24.3.September (2018):2073-2095

Denpasar memiliki serapan dana terbesar di provinsi Bali. Penelitian ini menggunakan tujuh variabel bebas yaitu: keterlibatan pemakai dalam proses pengembangan sistem informasi $\left(\mathrm{X}_{1}\right)$, kemampuan teknik personal sistem informasi $\left(\mathrm{X}_{2}\right)$, dukungan manajemen puncak $\left(\mathrm{X}_{3}\right)$, formalisasi pengembangan sistem informasi $\left(\mathrm{X}_{4}\right)$, program pelatihan dan pendidikan pemakai $\left(\mathrm{X}_{5}\right)$, keberadaan dewan pengarah sistem informasin $\left(\mathrm{X}_{6}\right)$, dan lokasi dari departemen sistem informasi $\left(\mathrm{X}_{7}\right)$, serta satu variabel terikat yaitu, kinerja sistem informasi akuntansi yang diukur menggukanan kepuasan pengguna sistem sebagai variabel terikat (Y).

Populasi dalam penelitian ini adalah BPR yang berada di Kota Denpasar yang berjumlah 13 unit sesuai dengan data yang bersumber dari Perbarindo DPK Denpasar. Teknik pengambilan sampel yang digunakan dalam penelitian ini adalah teknik sampel jenuh. Sampel dalam penelitian ini adalah para karyawan dan staff yang terlibat langsung dalam penggunaan SIA pada BPR di Kota Denpasar yang berjumlah 76 orang. Metode pengumpulan data yang digunakan dalam penelitian ini adalah dengan menggunakan kuesioner. Kuesioner disebarkan langsung kepada sasaran responden ke setiap BPR yang telah ditentukan. Teknik analisis data dalam penelitian ini diawali dengan pengujian instrumen, yaitu dengan menguji validitas dan reliabilitas. Dilanjutkan dengan uji asumsi klasik, analisis regresi linier berganda, uji kelayakan model (uji F), uji hipotesis (uji t). 


\section{HASIL DAN PEMBAHASAN}

Penelitian ini melakukan pengujian validitas dan reliabilitas terhadap kuisioner penelitian yang digunakan. Hasil pengujian menyatakan bahwa seluruh pernyataan dalam kuisioner dapat dikatakan valid dan reliabel. Ini berarti kuisioner layak digunakan untuk mecari data. Hasil pengolahan data yang dilakukan dengan uji linier berganda dapat dilihat pada Tabel 1.

Tabel 1

Hasil Analisis Regresi Linear Berganda

\begin{tabular}{lccc}
\hline \multirow{2}{*}{\multicolumn{1}{c}{ Variabel }} & $\mathbf{Y}=\boldsymbol{\alpha}+\boldsymbol{\beta}_{\mathbf{1}} \mathbf{X}_{\mathbf{1}}+\boldsymbol{\beta}_{\mathbf{2}} \mathbf{X}_{\mathbf{2}}+\boldsymbol{\beta}_{\mathbf{3}} \mathbf{X}_{\mathbf{3}}+\boldsymbol{\beta}_{\mathbf{4}} \mathbf{X}_{\mathbf{4}}+\boldsymbol{\beta}_{\mathbf{5}} \mathbf{X}_{\mathbf{5}}+\boldsymbol{\beta}_{\mathbf{6}} \mathbf{X}_{\mathbf{6}}+\boldsymbol{\beta}_{7} \mathbf{X}_{7}+\boldsymbol{\mu}$ \\
\cline { 2 - 4 } & $\begin{array}{c}\text { Koefisien } \\
\text { Regresi }\end{array}$ & t-test & Sig-t \\
\hline Constant & 1,766 & 6,920 & 0,000 \\
Keterlibatan pemakai dalam & 0,259 & 1,522 & 0,013 \\
pengembangan SIA & 0,610 & 2,049 & 0,044 \\
Kemampuan teknik personal & 0,123 & 2,269 & 0,026 \\
Dukungan Manajemen Puncak & 0,061 & 1,404 & 0,016 \\
Formalisasi pengembangan sistem & 0,154 & 3,294 & 0,002 \\
Program Pelatihan dan pendidikan & 0,159 & 2,602 & 0,011 \\
Dewan Pengarah Sistem Informasi & 0,227 & 1,522 & 0,001 \\
Lokasi Departemen Sistem Informasi & 0,560 & & \\
\hline Adjusted (R ${ }^{2}$ ) & 14,652 & & \\
F Hitung & 0,000 & & \\
Signifikan F & & & \\
\hline Sumber: Pengolahan data SPSS, 2018 & & & \\
\hline
\end{tabular}

Berdasarkan Tabel 1 Persamaan regresi yang dapat dirumuskan adalah sebagai berikut :

$Y=1,766+0,259+0,610+0,123+0,061+0,154+0,159+0,227+\mu$ 
ISSN: 2302-8556

E-Jurnal Akuntansi Universitas Udayana Vol.24.3.September (2018):2073-2095

Model persamaan regresi diatas diuji melalui pengujian asumsi klasik. Hasil uji menyatakan bahwa model berdistribusi normal, tidak mengandung gejala multikolinearitas dan gejala heteroskedastisitas. Berdasarkan hasil pengujian, dapat disimpulkan bahwa model yang dibuat dapat digunakan untuk melihat kecocokan model ( $R$ Square), kelayakan model (Uji F), dan untuk pengujian hipotesis.

Nilai Adjusted $R$ Square sebesar 0,56 ini berarti dalam model regresi yang terbentuk variabel kinerja sistem informasi akuntansi yang diukur dengan kepuasan pemakai (Y) dapat dijelaskan oleh variabel $X_{1}-X_{7}$ sebesar $56 \%$, sisanya $44 \%$ dijelaskan oleh variabel lain yang tidak dimasukkan dalam penelitian. Nilai sig. 0,000 yang ditunjukkan pada hasil uji kelayakan model lebih kecil dari nilai $\alpha(0,05)$ yang berarti bahwa model regresi yang terbentuk layak untuk digunakan dalam penelitian ini.

Berdasarkan Tabel 1 hasil analisis data variabel keterlibatan pemakai $\left(\mathrm{X}_{1}\right)$ dalam proses pengembangan sistem menunjukkan nilai signifikan sebesar $0,013<$ 0,05 sehingga keterlibatan pemakai dalam proses pengembangan sistem berpengaruh positif dan signifikan terhadap kinerja SIA. Koefisien regresinya menunjukkan nilai 0,259 yang bernilai positif. Berdasarkan hal tersebut maka hipotesis pertama dalam penelitian ini yaitu keterlibatan pemakai dalam proses pengembangan sistem berpengaruh positif pada kinerja SIA pada BPR di Kota Denpasar adalah diterima. Hasil penelitian ini sejalan dengan hasil penelitian Abhimantra (2016) dan Damana (2016) yang menyatakan bahwa keterlibatan pemakai dalam proses pengembangan 
sistem berpengaruh positif pada kinerja SIA. Dapat disimpulkan bahwa semakin banyak partisipasi pengguna dalam pengembangan sistem informasi dapat meningkatkan komitmen keterlibatan pemakai sistem sehingga meningkatkan kualitas SIA.

Berdasarkan Tabel 1 hasil analisis data variabel kemampuan teknik personal sistem informasi $\left(\mathrm{X}_{2}\right)$ menunjukkan nilai signifikan sebesar 0,044 $<0,05$ sehingga kemampuan teknik personal sistem informasi berpengaruh positif dan signifikan terhadap kinerja SIA. Koefisien regresinya menunjukkan nilai 0,610 yang bernilai positif. Berdasarkan hal tersebut maka hipotesis kedua dalam penelitian ini yaitu kemampuan teknik personal sistem informasi berpengaruh positif pada kinerja SIA pada BPR di Kota Denpasar adalah diterima. Hasil penelitian ini sejalan dengan hasil penelitian Dharmayanti (2015) dan Abhimantra (2016) yang menyatakan bahwa kemampuan teknik personal sistem informasi berpengaruh positif pada kinerja SIA. Dapat disimpulkan bahwa semakin tinggi kemampuan teknik personal SIA maka akan meningkatkan kinerja SIA dan pekerjaan semakin efektif. Hal tersebut mengindikasikan kepuasan karyawan dalam penggunaan SIA.

Berdasarkan Tabel 1 hasil analisis data variabel dukungan manajemen puncak $\left(\mathrm{X}_{3}\right)$ menunjukkan nilai signifikan sebesar $0,026<0,05$ sehingga dukungan manajemen puncak berpengaruh positif dan signifikan terhadap kinerja SIA. Koefisien regresinya menunjukkan nilai 0,123 yang bernilai positif. Berdasarkan hal tersebut maka hipotesis keempat dalam penelitian ini yaitu dukungan manajemen 
ISSN: 2302-8556

E-Jurnal Akuntansi Universitas Udayana Vol.24.3.September (2018):2073-2095

puncak berpengaruh positif pada kinerja SIA pada BPR di Kota Denpasar adalah diterima. Hasil penelitian ini sejalan dengan hasil penelitian Antari (2015) dan Abhimantra (2016) yang menyatakan dukungan manajemen puncak berpengaruh positif pada kinerja SIA. Dapat disimpulkan bahwa semakin tinggi dukungan yang diberikan oleh manajemen puncak maka akan meningkatkan kinerja SIA. Hal tersebut akan menyebabkan kepuasan terhadap pengguuna sistem informasi sehingga kinerja SIA akan menjadi lebih baik.

Berdasarkan Tabel 1 hasil analisis data variabel formalisasi pengembangan sistem $\left(\mathrm{X}_{4}\right)$ menunjukkan nilai signifikan sebesar 0,016 $<0,05$ sehingga formalisasi pengembangan sistem berpengaruh positif dan signifikan terhadap kinerja SIA. Koefisien regresinya menunjukkan nilai 0,061 yang bernilai positif. Berdasarkan hal tersebut maka hipotesis kelima dalam penelitian ini yaitu formalisasi pengembangan sistem berpengaruh positif pada kinerja SIA pada BPR di Kota Denpasar adalah diterima. Hasil penelitian ini sejalan dengan hasil penelitian Gunawati (2013) dan Abhimantra (2016) yang menyatakan formalisasi pengembangan sistem berpengaruh positif pada kinerja SIA. Dapat disimpulkan bahwa pengembangan sistem secara sistematik akan meningkatkan kinerja SIA. Semakin tinggi penguasaan dalam proses pengembangan sistem yang didokumentasikan dan disosialisasikan dengan baik akan meningkatkan keberhasilan penerapan dan kepuasan pengguna sistem.

Berdasarkan Tabel 1 hasil analisis data variabel program pelatihan dan pendidikan pemakai sistem $\left(\mathrm{X}_{5}\right)$ menunjukkan nilai signifikan sebesar $0,002<0,05$ 
sehingga program pelatihan dan pendidikan pemakai berpengaruh positif dan signifikan terhadap kinerja SIA. Koefisien regresinya menunjukkan nilai 0,154 yang bernilai positif. Berdasarkan hal tersebut maka hipotesis keenam dalam penelitian ini yaitu program pelatihan dan pendidikan berpengaruh positif pada kinerja SIA pada BPR di Kota Denpasar adalah diterima. Hasil penelitian ini sejalan dengan hasil penelitian Damana (2016) dan Abhimantra (2016) yang menyatakan program pelatihan dan pendidikan berpengaruh positif pada kinerja SIA. Dapat disimpulkan bahwa kinerja SIA akan meningkat bila terdapat program pelatihan dan pendidikan pemakai. Pelatihan dan pendidikan bagi pemakai sistem akan dapat memberikan kemampuan lebih terhadap pemakai sistem tersebut dan memberikan keterampilan dalam pengambilan keputusan, sehingga dapat memaksimalkan kinerja para pemakainya yang menghasilkan kepuasan bagi pemakainya, dengan demikian kinerja SIA juga menjadi lebih baik.

Berdasarkan Tabel 1 hasil analisis data variabel keberadaan dewan pengarah sistem informasi $\left(\mathrm{X}_{6}\right)$ menunjukkan nilai signifikan sebesar 0,011 $<0,05$ sehingga keberadaan dewan pengarah sistem informasi berpengaruh positif dan signifikan terhadap kinerja SIA. Koefisien regresinya menunjukkan nilai 0,159 yang bernilai positif. Berdasarkan hal tersebut maka hipotesis ketujuh dalam penelitian ini yaitu keberadaan dewan pengarah sistem informasi berpengaruh positif pada kinerja SIA pada BPR di Kota Denpasar adalah diterima. Hasil penelitian ini sejalan dengan hasil penelitian Gunawati (2013) dan Antari (2015) yang menyatakan keberadaan dewan 
ISSN: 2302-8556

E-Jurnal Akuntansi Universitas Udayana Vol.24.3.September (2018):2073-2095

pengarah sistem informasi berpengaruh positif pada kinerja SIA. Hasil uji ini berarti, apabila dewan pengarah menjalankan tugasnya dengan baik, maka kinerja SIA juga akan baik, karena semua masalah dalam penggunaan sistem tersebut akan dengan cepat diselesaikan, sehingga memberikan kepuasan bagi karyawan selaku pengguna sistem tersebut.

Berdasarkan Tabel 1 hasil analisis data variabel lokasi departemen sistem informasi $\left(\mathrm{X}_{7}\right)$ menunjukkan nilai signifikan sebesar 0,001 $<0,05$ sehingga lokasi departemen sistem informasi berpengaruh positif dan signifikan terhadap kinerja SIA. Koefisien regresinya menunjukkan nilai 0,227 yang bernilai positif. Berdasarkan hal tersebut maka hipotesis kedelapan dalam penelitian ini yaitu pemisahan lokasi departemen sistem informasi berpengaruh positif pada kinerja SIA pada BPR di Kota Denpasar adalah diterima. Hasil penelitian ini sejalan dengan hasil penelitian Antari (2015) dan Gunawati (2013) yang menyatakan pemisahan lokasi departemen sistem informasi berpengaruh positif pada kinerja SIA. Hasil uji ini berarti, apabila keberadaan departemen sistem informasi terpisah dari departemen lainnya, maka pemenuhan terhadap informasi akan semakin efektif, karen departemen sistem informasi akan lebih fokus dalam bekerja sehingga informasi yang dihasilkan lebih relevan dan handal.

\section{SIMPULAN}

Berdasarkan hasil pengujian hipotesis yang telah diuraikan maka dapat disimpulkan bahwa faktor keterlibatan pemakai dalam pengembangan sistem informasi, 
kemampuan teknik personal sistem informasi, dukungan manajemen puncak, formalisasi pengembangan sistem informasi, program pelatihan dan pendidikan pemakai, keberadaan dewan pengarah sistem informasi, pemisahan lokasi departemen sistem informasi akuntansi secara simultan berpengaruh signifikan terhadap kinerja sistem informasi akuntansi pada BPR di Kota Denpasar. Hal ini ditunjukan dengan nilai adjusted $R$ square sebesar 0,560 yang berarti bahwa 56 persen dari kinerja SIA pada BPR di Kota Denpasar dipengaruhi oleh faktor-faktor yang diikutsertakan di dalam model.

Dari simpulan diatas saran yang dapat diberikan adalah 1) berdasarkan tabel 1 nilai Adjusted $\left(\mathrm{R}^{2}\right)$ menjelaskan bahwa $44 \%$ kinerja SIA dipengaruhi oleh faktor lain yang tidak diikutsertakan ke dalam model regresi sehingga penelitian selanjutnya diharapkan dapat menambah faktor lainnya yang belum dimasukkan ke dalam penelitian ini, seperti konflik antar pengguna SIA, karena kinerja SIA akan lebih baik apabila tidak ada konflik anatar pengguna SIA, 2) manajemen Bank Perkreditan Rakyat di Kota Denpasar perlu memperhatikan saran-saran karyawan terhadap SIA untuk dijadikan acuan dalam pengembangan sistem sehingga menjadi lebih baik lagi, lebih mendukung penggunaan SIA pada masing-masing bagian, sehingga karyawan juga termotivasi untuk menggunakan SIA.

\section{REFERENSI}

Abhimantra, Wayan Purwa dan I Ketut Suryanawa. 2016. Analisis Faktor-Faktor yang Memengaruhi Kinerja Sistem Informasi Akuntansi. E-Jurnal Akuntansi Universitas Udayana, 14(3), h: 1782-1809. 
ISSN: 2302-8556

E-Jurnal Akuntansi Universitas Udayana Vol.24.3.September (2018):2073-2095

Adventri, Beriyaman. 2008. Analisis Faktor-Faktor Yang Mempengaruhi Kinerja Sistem Informasi Akuntansi (Survei Terhadap Tiga Badan Usaha Milik Negara di Bandung. Skripsi Sarjana Jurusan Akuntansi pada Fakultas Ekonomi Universitas Widyatama.

Al-eqab, M. and Adel, D. 2013. The Impact of IT Sophistications on the Perceived Usefulness of Accounting Information Characteristics among Jordanian Listed Companies. Journal of Bussiness and Social Science, 4 (3). pp: 145-155.

Almilia, L. S. dan I. Briliantien .2007. Faktor-faktor yang Mempengaruhi Kinerja Sistem Informasi Akuntansi Pada Bank Umum Pemerintah di Wilayah Surabaya dan Sidoarjo, http://spicaalmilia.files.wordpress.com /2007/03/artikel-penelitian-kinerja-sistem-informasi.pdf. Diunduh pada tanggal 12 April 2017

Amrul, Sadat, dan Ahyadi Syar'ie. 2005. Analisis beberapa Faktor-faktor yang Mempengaruhi Kinerja SIA. Simposium Nasional Akuntansi VIII. Solo.

Antari, Kadek Rilly Wdihi, I Putu Gede Diatmika dan I Made Pradana Adi Putra. 2015. Faktor-Faktor yang Berpengaruh Terhadap Kinerja Sistem Informasi Akuntansi pada Bank Perkreditan Rakyat di Kabupaten Buleleng. E-Journal S1 Ak Universitas Pendidikan Ganesha, 14(1).

Arfan, Ikhsan. 2008. Metode Penelitian Akuntansi Keprilakuan. Yogyakarta: Graha Ilmu.

Baig, A. H. and Gururajan, R. 2011. Preliminary Study to Investigation the Determinants that Effect IS/IT Outsourcing. Journal of Information and Communication Technology Research, 1 (2). pp: 48-54.

Baridwan, Zaki. 2010. Sistem Informasi Akuntansi. Edisi kelima. Yogyakarta: BPFE.

Beke, Jeno. 2010. Review of International Accounting Information Sistem. Journal Of Accounting and Taxation 2(2), pp: 025-030.

Bodnar, George H. dan William Hopwood S. (Amir Abadi Jusup dan Rudi M. Tambuan, penerjemah). 2001. Sistem Informasi Akuntansi. Jakarta : Salemba Empat.

Budiartha, Ketut. 2007. Pengaruh Kemampuan terhadap Partisipasi dan Penermaan Sistem serta Kepuasan Pengguna Sistem Informasi pada Hotel Berbintang di 
Provinsi Bali. Disertasi Doktor Jurusan Akuntansi pada Universitas Airlangga Surabaya.

Cudanov, Mladen, Ondrej Jasko and Gheorghe Savoiu. 2010. Interrelationships Of Organization Size and Information and Communication Technology Adoption. Journal of Applied Quantitative Methods 5(1).

Choe, J. M. 1996. The Relationships Among Performance Of Accounting Information Sistems, Influence Factors, And Evolution Level Of Information Sistems. Journal Of Management Information Sistem. 12(4), pp: 215-239.

Dalci, Ilhan, and Veyis Naci Tanis 2003. Benefit of Computerized Accounting Information Sistem on the JIT Production Sistem, Review of Social, Economic \& Business Studies, Vol 2, No 11, pg 45-64.

Darsono, Li. 2005. Examining Information Technology Acceptance By Individual Professionals. Gadjah Mada International Journal of Business 7(3), pp: 155178.

Davis, F. D. (1986). A technology acceptance model for empirically testing new enduser information sistems: Theory and results. Doctoral dissertation. Cambridge, MA: MIT Sloan School of Management.

Dey, Shikha. 2007. Accounting Information Sistem in Commercial Banks-An Evaluation in Bangladesh, The Bangladesh Accountant.

Dharmayanti, Ni Made dan Made Sadha Suardikha. 2015. Analisis Faktor-Faktor yang Mempengaruhi Kinerja Manajemen Akibat Penggunaan Sistem Informasi Akuntansi. E-Jurnal Akuntansi Universitas Udayana, 12(2), h: 409-421.

Dianawati, Ketut. 2011. Analisis Faktor-faktor yang Berpengaruh pada Pengembangan Kualitas Sistem Informasi Akuntansi di Lembaga Perkreditan Desa (LPD) Kecamatan Mengwi. Skripsi Sarjana Jurusan Akuntansi pada Fakultas Ekonomi Universitas Udayana Denpasar.

Diputra, Dewa Gede Anggada Sayoga. 2012. Faktor-faktor yang Mempengaruhi Kinerja Sistem Informasi Akuntansi pada Bank Perkreditan Rakyat di Kabupaten Tabanan. Skripsi Sarjana Jurusan Akuntansi pada Fakultas Ekonomi Universitas Udayana Denpasar.

Fitri, Nuril. 2012. Faktor-faktor yang Mempengaruhi Kinerja Sistem Informasi Akuntansi pada Perusahaan Farmasi di Medan. Tesis Sekolah Pascasarjana pada Universitas Sumatera Utara Medan. 
ISSN: 2302-8556

E-Jurnal Akuntansi Universitas Udayana Vol.24.3.September (2018):2073-2095

Ghozali, Imam. 2011. Aplikasi Analisis Multivariate dengan program SPSS. Cetakan IV. Semarang: Badan Penerbit Universitas Diponegoro.

Gunawati, Ni Made Fitri. 2013. Faktor-faktor yang Mempengaruhi Kinerja Sistem Informasi Akuntansi pada Bank Umum Pemerintah di Kota Denpasar. Skripsi Jurusan Akuntansi Fakultas Ekonomi Universitas Warmadewa.

Hall, J. A. 2009. Sistem Informasi Akuntansi. Edisi 4.Jakarta: Salemba Empat.

Hendarti, Henny, dan Anderes Gui.2008. Korelasi Antara Efektifitas Sistem Informasi Penjualan Dengan Kinerja User. Seminar Nasional Aplikasi Teknologi Informasi 2008 (SNATI 2008).

Hutapea, Johanes Edward. 2016. Faktor-faktor yang Mempengaruhi Kinerja Sistem Informasi Akuntansi pada Bank Umum Pemerintah di Kota Denpasar. Skripsi Jurusan Akuntansi Fakultas Ekonomi Universitas Warmadewa.

Ilat, Ventje, Winston Pontoh, Inggriani Elim, Sonny Pangerapan, Imelda Najoan. 2008. Faktor-faktor yang Mempengaruhi Kinerja Sistem Informasi Akuntansi pada Usaha Perbankan di Manado. Satuan Kerja UNSRAT-DEPDIKNAS.

Indriati, Lia. 2010. Faktor-faktor yang mempengaruhi Pengembangan Sistem Informasi Akuntansi Pada Putra Guna Jaya Mulia Surabaya. Skripsi Jurusan Akuntansi Fakultas Ekonomi Universitas Pembangunan Nasional. Surabaya.

Jen, Tjhai Fung. 2002. Faktor-Faktor Yang Mempengaruhi Kinerja Sistem Informasi Akuntansi. Jurnal Bisnis Akuntansi. (4:2) PP 135:154

Jogiyanto. 2005. Sistem Informasi Berbasis Komputer. Edisi ke-3. Yogyakarta: BPFE.

Kariyani. 2006. Faktor-Faktor yang Berpengaruh Terhadap Kinerja Sistem Informasi Akuntansi Pada Biro Perjalanan Wisata di Propinsi Bali. Skripsi. Fakultas Ekonomi Universitas Udayana.

Kharisma, Made Dwinda dan Ida Bagus Dharmadiaksa. 2015. Pengaruh Keterlibatan Pengguna dan Ukuran Organisasi pada Efektivitas penggunaan Sistem Informasi Akuntansi. E-Jurnal Akuntansi Universitas Udayana, 10(3), h: 876881.

Komara, Acep. 2006. Analisis Faktor-faktor yang Mempengaruhi Kinerja Sistem Informasi Akuntansi. Jurnal Maksi, 6 (2): h: 143-160. 
Lau, Elfreda Aplonia. 2004. Pengaruh Partisipasi Pemakai Terhadap Kepuasan Pemakai dalam Pengembangan Sistem Informasi dengan Lima Variabel Moderating. Jurnal Riset Akuntansi Indonesia 7(1): h: 23-43.

Mahsun, M. F. Sulistiyowati, dan H. A. Purwanugraha. 2006. Akuntansi Sektor Publik. Yogyakarta: BPFE.

McKeen, James D, Tor Gulmaraes and James C. Watherbe. 1994. The Relationship Between User Participation And User Satisfaction.

Nithyanandam, K. E. Kanniyapan, M. Arul Dhanakar and V. Rajasekar. 2006. User Education Programmes And Academic Libraries. International Convention Caliber 2-4 February

Perbarini, Ni Kadek Ayu. 2012. Analisis Faktor-Faktor Yang Mempengaruhi Kinerja Sistem Informasi Akuntansi pada Lembaga Perkreditan Desa di Kecamatan Denpasar Utara. Skripsi. Fakultas Ekonomi Universitas Udayana.

Perdana, Putu Ngurah Indra. 2011. Analisis Faktor-Faktor yang Mempengaruhi Kinerja Sistem Informasi Akuntansi Pada Hotel-Hotel Berbintang di Kota Denpasar. Skripsi Sarjana Jurusan Akuntansi pada Fakultas Ekonomi Universitas Udayana. Denpasar.

Sandhu, K. 2008. Information Quality for a University Accounting Information Sistem. http://ssrn.com/abstract=1289508.

Sori, Zulkarnain Muhamad. 2009. Accounting Information Sistem (AIS) and Knowledge Management. American Journal of Scientific Research.

Sugiyono, 2013. Metode Penelitian Bisnis, Cetakan Keempat. Bandung. Alfabeta.

Terry, Julian and Craig Standing. 2004. The Value Of User Participation In Ecommerce Sistem Development. Informing Science Journal 7.

Tian-Hui, Zhu. 2009. Library User Education Under The Circumstance Of Network. Us-China Education Review 6 (12).

Tokic, Marija, Mateo Spanja, Iva Tokic, Ivona Blazevic. 2011. Functional Structure of Entrepreneurial Accounting Information Sistems. International Journal Of Engineering 9 (2).

Utama, I Dewa Gede Buda dan I Made Sadha Suardikha. 2014. Faktor-faktor yang Mempengaruhi Kinerja Sistem Akuntansi pada Lembaga Perkreditan Desa. EJurnal Akuntansi Universitas Udayana, 9(3), h: 728-746 
ISSN: 2302-8556

E-Jurnal Akuntansi Universitas Udayana Vol.24.3.September (2018):2073-2095

Wirawan, Bima Satya dan I Made Sadha Suardikha. 2016. Faktor-faktor yang Mempengaruhi Kinerja Individual pada Bank Perkreditan Rakyat di Kabupaten Badung. E-Jurnal Akuntansi Universitas Udayana, 17(3), h: 2352-2383.

Wrastuti, A.A. Sg. Istri Mas. 2009. Analisis Faktor-faktor yang Mempengaruhi Kinerja Sistem Informasi Akuntansi Pada Bank Perkreditan Rakyat di kota Denpasar. Skripsi Sarjana Jurusan Akuntansi pada Fakultas Ekonomi Universitas Udayana. Denpasar.

Xu, Hongjiang and Dandong Lu. 2003. The Critical Success Factors For Data Quality In Accounting Information Sistem Different Industries' perspective. IACIS 